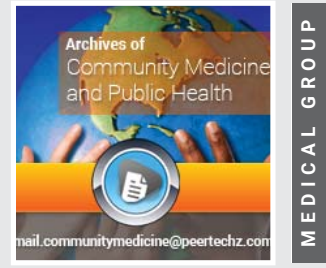

\section{Phased Reopening during COVID-19 in a nut shell}

\author{
Joshua Chadwick Jayaraj*
}

Nalatham Charitable Trust Clinic, Chennai, India

As the COVID-19 pandemic is rapidly progressing, most countries have implemented physical distancing measures community-wide. As transmission dynamics begin to decline, along with incidence of COVID-19 cases, there will be a need for decisions at the country level about how to transition out of strict physical distancing and into a phased reopening.

Models have shown that, in the absence of social distancing, COVID-19 has a Reproduction rate (Ro) of between 2 and 3, this means, on average every person with the disease will spread it to 2 to 3 others [1]. To end an epidemic, control measures have to be in place to drive that number as far below 1 as possible. Meanwhile, social distancing measures, combined with casebased interventions, are the key tools to maintaining the Ro below 1 [2]. If the Ro rises above 1, this means the curve has been heightened. If that occurs, it may be necessary to re-initiate large-scale physical distancing. It is important to recognize that countries will need to actively manage COVID-19 cases with surveillance for the entire duration of the pandemic until a safe and effective vaccine is widely available.
Received: 21 April, 2020

Accepted: 25 April, 2020

Published: 27 April, 2020

*Corresponding author: Joshua Chadwick Jayaraj, Nalatham Charitable Trust Clinic, Chennai, India, E-mail: joshuachadwick89@gmail.com

https://www.peertechz.com

Check for updates

\begin{tabular}{|l|l|l|}
\hline Phases & Goals & Thresholds for action
\end{tabular}

\section{Phases}

Goals

Thresholds for action

To slow the spread in this period, schools are closed across the country,

workers are being asked to do their jobs from home

when possible, community gathering spaces such as

1) To ask community- malls and gyms are closed, and restaurants level physical distancing are being asked to limit their services. These measures to "slow the measures will need to be in place in each state spread."[4]

Phase I until transmission has measurably slowed

2) To increase access to down and health infrastructure can be scaled diagnostic testing and increase public health and medical system capacities. up to safely manage the outbreak and care for the sick.

These capacities are needed to safely identify and treat all COVID-19 patients and to prepare for a shift from community mitigation (what we are doing now) to case-based interventions (when we try to control spread by focusing testing and resources on individuals with disease who may be infectious and their close contacts).
As we transition out to phase II, economies can begin a process of reopening, with modifications. Rather than asking everyone to stay home, countries can limit SARS-CoV-2 transmission through a combination of physical distancing and case-based interventions (testing, contact tracing, and selfisolation for those with active disease or individuals who may have contracted SARS-CoV-2 and are awaiting test results), which in most places may require an expanded workforce and resources.

This document is limited to phases of reopening and does not address other important matters related to the risk of SARS-CoV-2 transmission in businesses, schools, etc. which are considered nonessential by countries.

This table summarizes 4 phases and identified capacities required in each phase, as well as the triggers needed to progress from one phase to the next [3].

Based on the public health principles [7], coming days will have the following in place until we have a therapeutic option

\section{Triggers for transitioning to next phase \\ Steps required}

When following 4 criteria have been met [5]

(1) the number of new cases has declined for at least 14 days; (2) rapid diagnostic testing capacity is sufficient to test, at minimum, all people with COVID-19 symptoms, as well as close contacts and those in essential roles;

(3) the healthcare system is able to safely care for all patients, including having appropriate personal protective equipment for healthcare workers; and (4) there is sufficient public health capacity to conduct contact tracing for all new cases and their close contacts.
These capacities are needed to safely identify and treat all COVID-19 patients and to prepare for a shift from community mitigation (what we are doing now) to casebased interventions (when we try to control spread by focusing testing and resources on individuals with disease who may be infectious and their close contacts). Issuing stay-at-home advisories in hot spots where transmission is particularly intense (i.e., when case counts are doubling in a

city or
locality every three to five days); and

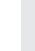


Reopen, State by distancing measures in a reopening, with modifications.

State concerted and carefu fashion,

For older adults

2) Allow the vast (those over age 60), those with underlying majority of businesses health

3) Continue to transmission

so we do not revert back to Phase I. control SARS-CoV-2

restrictions and other Phase II measures can be lifted when safe to wear fabric nonmedical face masks while and effective tools for mitigating in the community to reduce their risk of the risk of asymptomatic spread [6]

COVID-19 are available, including Testing should become more widespread and routine as point-of-care diagnostics are fully deployed in doctors' offices.

Rather than asking everyone to stay home, states can limit SARS-CoV-2 transmission through a combination of physical distancing and case-based interventions (testing, contact tracing, and self-isolation for those with active disease or individuals who may have contracted SARS-CoV-2 and are awaiting test results), which in most places may require an expanded workforce and resources.

Looks ahead to a time when an While we need to better understand the effective therapeutic or vaccine is strength of the immune response in mild available. cases and how long people remain immune Serological Surveys to Determine from reinfection, we know there is a period Population safe and effective vaccine starts to become outcomes;

new prioritization guidance for the

Establish

Protection

Then Lift Al

Restrictions

3) Provide a prophylaxis for those exposed to infection to prevent them from developing Mass Vaccination or Therapeutic DistributionWhen Supply Is Abundant. disease or reduce its severity;

4) In the case of

a vaccine, build population-leve immunity to the virus in order to reduce illness and death and stop or greatly slow spread; and 5) Enable the lifting of all physical distancing measures.

Phase IV Rebuild Our Readiness Global Vaccine Scale-Up and Vaccination.

Immunity: If a sufficiently high fraction of the population has become immune either through natural recovery or vaccination, remaining restrictions can be lifted where most people will have sufficient antibodies to offer protection. for the Next Pandemic Identifies some policy

priorities for increasing preparedness for the

1) Develop Vaccines for Novel Viruses in Months, Not Years;

next public health threat System
3) Establish a National Infectious Disease
Forecasting Center; and
4) Governance

Will require investment into research and development initiatives, expansion of public health and health care infrastructure and workforce, and clear governance structures to execute strong preparedness plans. Properly implemented, the steps described here also

provide the foundation for containing the damage that future pathogens may cause. or an effective vaccine:

1. Physical Distancing- wherever possible people will work or access the business from home; needs restructuring responsibilities to minimize the number of workers that need to be physically present.

2. Engineering controls- creating physical barriers between people (ideally, at least 6 feet).

3. Administrative controlso-redistributing responsibilities to reduce contact between individuals, using technology to facilitate communication.

4. PPE- Wearing non medical cloth masks.

This document briefly summarizes the phases of reopening.
Decisions should be made carefully and thoughtfully to limit the risk of second wave of the disease [8].

\section{References}

1. Sanche S, Lin YT, Xu C, Romero-Severson E, Hengartner N, et al. (2020) High Contagiousness and Rapid Spread of Severe Acute Respiratory Syndrome Coronavirus 2. Emerg Infect Dis 26. Link: https://bit.ly/2VCyTiM

2. Ridenhour B, Kowalik JM, Shay DK (2018) Unraveling R0: Considerations for public health applications. Am J Public Health 108: S445-S454. Link: https://bit.ly/3bOyEqx

3. Mcclellan MB, Silvis L, Gottlieb S, Rivers C, Watson C (2020) National Coronavirus Response. 1-16. Link: https://bit.ly/2zv4sIT

4. 15 Days to Slow the Spread. The White House. Link: https://bit.ly/3ePfUJd

5. CDC (2020) Interim US Guidance for Risk Assessment and Public Health 
Management of Persons with Potential Coronavirus Disease 2019 (COVID-19) Exposures: Geographic Risk and Contacts of Laboratory-Confirmed Cases. Link: https://bit.ly/2zvrtVN

6. Feng S, Shen C, Xia N, Song W, Fan M, et al. (2020) Rational use of face masks in the COVID-19 pandemic. Lancet Respir Med Link: https://bit.ly/2VzqPiG
7. Martin E, Rivers C, Gottlieb S, Watson C, Schoch-Spana M, et al. (2020) Public Health Principles for a Phased Reopening During COVID-19: Guidance for Governors. Johns Hopkins Center for Health Security. Link: https://bit.ly/35bPFZa

8. Xu S, Li Y (2020) Comment Beware of the second wave of COVID-19. Lancet 395: 1321-1322. Link: https://bit.ly/3bEChin

\section{Discover a bigger Impact and Visibility of your article publication with}

\section{Peertechz Publications}

\section{Highlights}

* Signatory publisher of ORCID

* Signatory Publisher of DORA (San Francisco Declaration on Research Assessment)

- Articles archived in worlds' renowned service providers such as Portico, CNKI, AGRIS, TDNet, Base (Bielefeld University Library), CrossRef, Scilit, J-Gate etc.

* Journals indexed in ICMJE, SHERPA/ROMEO, Google Scholar etc.

* OAI-PMH (Open Archives Initiative Protocol for Metadata Harvesting)

* Dedicated Editorial Board for every journal

* Accurate and rapid peer-review process

* Increased citations of published articles through promotions

* Reduced timeline for article publication

Submit your articles and experience a new surge in publication services (https://www.peertechz.com/submission).

Peertechz journals wishes everlasting success in your every endeavours.

Copyright: () 2020 Jayaraj JC. This is an open-access article distributed under the terms of the Creative Commons Attribution License, which permits unrestricted use, distribution, and reproduction in any medium, provided the original author and source are credited. 